\title{
EŞIKTTE DANS, PERFORMATİF İNŞA VE YIKICI-ARACI BİR KİMLİK OLARAK KÖÇEKLİK ${ }^{1}$
}

\section{Atilla BARUTÇU $\mathbf{U}^{2}$}

\section{ÖZ}

Günümüzdeki köçek performansını yeniden okuma girişiminde bulunan bu makale, köçekliğin performatif olduğunu, cinsiyet kategorilerinden bağımsız bir toplumsal kategori inşa ettiğini ve yıkıcıaracı olarak tanımlanabilecek geçici bir kimlik oluşumuna işaret ettiğini savunmaktadır. Makale, Türkiye'nin farklı şehirlerinde köçeklerle yapılan görüşmeleri, canlı köçek performansı gözlemlerini, video analizlerini ve film betimlemelerini içeren bir saha çalışmasına dayanmaktadır. Bu saha çalışmasının desteğiyle, köçek performansının ikili-karşıtlıkları yıkan ve kategorileri aşan bir uzam yarattığını öne sürmektedir. Bu uzamın eşikteliğe işaret ettiğini, eşikte gerçekleşen dansla köçeklerin normatif kategorileri sarstığını ve normatif olmayan yeni bir kimlik temsili aracılığıyla bütün kimliklerin toplumsal inşasını açık edecek ipuçları sunabildiğini tartışmaya açmaktadır.

Anahtar Kelimeler: Performatif, Eşiktelik, Kimlik, Performans, Köçek

\footnotetext{
${ }^{1}$ Bu makale 2019 yılında Ankara Üniversitesi Kadın Çalışmaları Anabilim Dalı'nda tamamladığım doktora tezimden üretilmiştir. Bu vesileyle tez danışmanım Prof. Dr. Güzin Yamaner'e, tez izleme komitemde yer alan Prof. Dr. Elif Ekin Akşit'e, Doç. Dr. Fatma Umut Beşpınar'a ve tez savunmamda bulunan Prof. Dr. Sibel Yardımcı'ya, Doç. Dr. Tuğba Taş'a değerli katkılarından dolayı bir kez daha teşekkür etmek isterim.

${ }^{2}$ Arş. Gör. Dr., Zonguldak Bülent Ecevit Üniversitesi Fen Edebiyat Fakültesi Sosyoloji Bölümü
} 


\title{
DANCE ON LIMINALITY, PERFORMATIVE CONSTRUCTION AND KÖÇEK AS A DESTRUCTIVE-MEDIATING IDENTITY
}

\begin{abstract}
This article attempts to reread today's Köçek performances and argues that the Köçeks represent a separate social category through the performative construction unique to them, and create an identity that can play a destructive-mediating role. With the field study that involves interviews with Köçeks in different cities of Turkey, observations on live performances and reviews of related videos/movies, this article asserts a claim that Köçek performance creates a space by destructing some binary oppositions and passing over some categories, and represents a liminal activity. It is discussed that the Köçeks have potential to undermine the normative categories with their dance on liminality, and offer some clues to express the social construction of all identities through representation of a new and non-normative one.
\end{abstract}

Keywords: Performative, Liminality, Identity, Performance, Köçek 


\section{Gíríş}

Dansın cinsiyetlendirilmiş bir alan olduğu ve pek çok dans formunun kadınlarla özdeşleştirildiği düşünüldüğünde dans eden erkeklerin çoğu zaman egemen erkeklik formuna uygun bir erkeklik modeli sunmadıkları söylenebilir. Yabancı literatürde erkeklik ve dans ilişkisine odaklanan öncü çalışmalar, bu ilişkiyi farklı coğrafyalarda farklı kesişimselliklerle ele alarak erkekliğin "erkek” görülmeyen bir alandaki sorunlu varlığını tartışır (Burt, 1995; Gard, 2001, 2006; Weber, 2003; Karayanni, 2004; Johnson, 2005; Rodosthenous, 2007; Fisher ve Shay, 2009; Bassetti, 2013). Türkiye'de ise doğrudan dans ve erkeklik ilişkisine dair biriken bir literatürün varlığından bahsetmek pek mümkün görünmemektedir.

Dansın daha çok kadınlarla ilişkilendirilmesinin altında çeşitli dinamikler yatar. Bunların başında beden ve cinselliğin geldiğini söylemek mümkündür. Johan Huizinga, “dansın güzelliği bizatihi hareket eden bedenin güzelliğidir” diye yazar (2017: 223). Dansta bedenin güzellik temsili, görsel bir unsur haline gelmesi, hareketliliğiyle bakışları üzerine çekmesi, estetik sunumu ve tüm bunlarla ilişkili olarak yaratabileceği cinsellik çağrışımı, pek çok kültürde yüceltilen normatif erkeklik kimliğine uygun görülmemesi sebebiyle erkekleri bu alandan dışlar. Cinsiyet ikiliğini izleyen-izlenen, bakan-bakılan, özne-nesne gibi karşıtlıklarla eşleştirir ve erkek-kadın arasındaki eşitsizliğe dayalı güç ilişkisi bu alanda da sürdürülmüş olur. Bu yüzden dansın kadınlara atfedilen bir alan olarak kurgulanması, dans eden erkeklerin öncelikli görülen kimliklerinde (yani cinsiyet kimliklerinde) bir kriz yaratabilir ve onları damgaya (stigma) maruz birakabilir (Gard, 2006; Risner, 2009; Bassetti, 2013). Erving Goffman'1n "normal” olanın karşısında onunla ilişkilendirilerek yaratılan "öteki” toplumsal kimliklere işaret etmek için öne sürdügü ve kavramsallaştırdığı damga (2014), dans eden erkekler özelinde düşünüldüğünde onların erkeklik kimliklerinde vuku bulur.

Dansın erkeklik performansıyla arasındaki gerilimin dansta sergilenen hareketlerden ve giyilen kıyafetlerden etkilendiği söylenebilir. Zira dansın kadınlarla ilişkilendirildiğine yönelik vurgunun bütün dans türleri için geçerli olduğunu düşünmek yanlış olur. Bugün hip hop gibi tüm dünyaya yayılmış popüler danslarda veya Haka dansı ve Zeybek gibi farklı coğrafyalardaki yerel danslarda erkeklerin ön 
planda olduğunu unutmamak gerekir. Bu yüzden dans k1yafetlerinin ve hareketlerinin bu alandaki cinsiyet dinamiklerine etki ettiğini özellikle vurgulamak gerekir. "Erkeksi” kodlarla bezenmiş hareketlerle ve kıyafetlerle gerçekleşen danslar, erkeklik performansı için zarar verici görülmeyebilir.

Öte yandan Gard (2001), “erkek dans etmez” şeklindeki genel yargının zaten artık geçerli olmadığından bahseder. Benzer şekilde Jowitt, dans eden erkeklerin sahnedeki temsillerinde artık daha özgür olduklarını ve imajlarını eskiden olduğu gibi önce erkek sonra dansçı olarak tanımlamadıklarını söyler (2010: 242). Ancak Türkiye kültürü için böylesi net bir dönüşümden bahsetmek kolay değildir. Dans eden erkeklerin hâlâ erkekliklerinin ön planda olduğu (yani önce erkek sonra dansçı oldukları) ya da erkekliklerinin dans performanslarından bağımsız düşünülemediği (yani “erkek dansçı” oldukları) söylenebilir. Öte yandan bu durum köçekler ve köçek performansı ele alındığında karmaşıklaşır. Çünkü köçek performansı cinsiyet kategorilerini altüst edip kendine has bir alan yaratarak ayrı bir noktada duruyor gibidir.

Günümüzdeki köçek performansına odaklanacak olan bu yazı, köçekliğin performatifliğine, yıkıcı etkisine, üreticiliğine ve normatif kimliklerin inşasını açık etmedeki aracı rolüne vurgu yapmaya çalışacak ve köçekliğin yıkıcı-aracı bir kimlik kategorisi olarak okunabileceğini öne sürecektir. Köçeklerin performans esnasında kendilerine has bir beden temsiliyle ve oluş halindeki özneyle başka kategorilerle açıklanamayacak bir uzam yarattıkları düşünülebilir. Bu uzam, köçeklerin performans esnasında bazı normatif kategorileri yerle bir etmesiyle ve/veya bazı ikili karşıtlıkları aynı anda içinde barındırmasıyla ortaya çıkar ve bu yönüyle liminal bir etkinliğe, yani eşikteliğe göz kırpar. Eşikteki dans, aynı esnada geçici bir kimlik kategorisini, yani köçek kimliğini de üretmiş olur. Bu kimlik geçicidir, normatif değildir ve olmayı da hedeflemez. Ama normatif görülen başka kimliklerin toplumsal inşasına ve akışkanlığına işaret etmek için aracı bir rol oynama potansiyeli taşır. Köçekliğin bu anlamda performatif olduğu ve yıkıcı-aracı bir pratiğe işaret ettiği söylenebilir.

Öte yandan köçek performansının normatif kategorilerin akışkanlığına işaret edebileceği argümanı, bizi köçekliğin bu etkiye sahip tek örnek olduğu çıkarımını yapma hatasına düşürmemelidir. Tarih boyunca 
özellikle dini ritüellerden oluşan performanslarda tıpkı köçeklikte olduğu gibi bazı "sınır" aşımları görmek mümkündür. İnsanların eski çağlarda dramatik canlandırmalar yaparken hayvan temsilleri gerçekleştirmeleri (James, 2013: 41), putperest ritüellerde, avcılık gösterilerinde, animizm ve totemizm gibi inançlarda boya, maske ve çeşitli cisimlerle bedenlerini çeşitli formlara sokmaları (Nutku, 2011: 18) ve özellikle Şamanizm'de bu canlandırmaların şifa ritüelleri ve ruh arayışı için önemli bir kamusal araç olarak kullanılması (de la Croix ve Tansey, 1986: 500) bu performanslara örnek verilebilir. Zaten genel olarak dansın (ve türlü seyirlik oyunların) kökeninin şamanlara dayandığg ve şamanların tarihteki ilk profesyonel dansçılar olarak görülebileceği söylenir (And, 2016; Davletov, 2017). Bu bağlamda kimi araştırmacıların Türk Tiyatro tarihinin ilk evresini şaman törenlerine dayandırması (Şener, 1999; Ünlü, 2006) ve daha sonra Geleneksel Halk Tiyatrosu evresinde köçekleri de görüyor oluşumuz anlamlıdır. ${ }^{3}$ Ancak köçeklik dahil kimi performanslarda şamanlığın izleri görülse de artık inanç faktörüne rastlamayız. Dolayısıyla dini ritüeller ile eğlence amaçlı danslar arasındaki bağlantının (ve aynı zamanda farkın) altını çizmek, köçekliğin kendine münhasır konumunu bir kez daha vurgulamak için önem arz eder.

Bu yazıda öncelikle köçeklerin günümüzdeki kendine has konumunu temellendirebilmek ve köçekliğin performatifliğini görünür kılabilmek için Judith Butler'ın performativite kuramındaki bazı temel argümanlar ele alınacaktır. Ardından bu araştırma için gerçekleştirilen saha çalışmasının detayları ve köçek kültürünün kısa tarihsel seyri verilip, elde edilen veriler üzerinden köçek performansının yıktığı sınırlar ve yarattığı geçici kimlik kategorisi tartışmaya açılacaktır.

\section{PERFORMATIF İNŞA}

Performativite kuramını açıklarken belki de vurgulanması gereken ilk şey, Butler'ın performativite ile performans arasına koyduğu mesafe olmalıdır. Butler, performativitenin performansa indirgenmesinin bir hata olacağını belirtir (2013: 135). Çünkü en basit haliyle performans, icra edilen şeyin icra

\footnotetext{
${ }^{3}$ Geleneksel Halk Tiyatrosu'nda köçekleri orta oyununda görürüz. Pişekar'ın halkı selamlayarak oyunu başlatmasından önceki curcuna bölümünde köçeklerin de dans ettiği, ancak bu bölümden zamanla vazgeçildiği söylenir (Sevengil, 2015, 68).
} 
edilmeden önce de var olduğuna ve onun bir tekrarına işaret eder. Performatif olanda vurgulanan şey ise icra edilenin hiçbir zaman önceden var olanla aynı olmadığı ve önceyi referans alsa dahi sürekli yeni bir şeyin icra edildiğidir. Butler, bu sebeple toplumsal cinsiyetin performatif olduğunu söyler. Bu sayede cinsiyetlere dair bir öz, bir hakikat olmadığını vurgular. Yani ona göre "toplumsal cinsiyet her zaman bir yapma edimidir, ama yapılandan önce var olduğu söylenebilecek bir özneye ait değildir” (Butler, 2010: 77). Özne, o edim esnasında var olur ve bu edimlerin tekrarı hiçbir zaman bir öncekinin aynısı olamaz.

Butler, bu argümanını “tekrar” kavramı üzerinde sıklıkla durarak daha anlaşılır kılar. Butler’a göre "toplumsal cinsiyet bedenin tekrar tekrar stilize edilmesidir, kaskatı bir düzenleyici çerçeve içinde tekrar edilen bir dizi edimdir. $\mathrm{Bu}$ edimler zamanla birleşerek töz görünümünü, bir çeşit doğal varlık görünümünü üretir” (2010: 89). Eğer toplumsal cinsiyet performatif ise bu öznenin bilinçli ve istekli bir biçimde kabulünden değil, tekrarlama yoluyla özneyi desteklemesindendir. Bu itibarla, performatiflik öznenin önkoşuludur (Jagose, 2015: 108). Ancak buradaki tekrar, performansın vurguladığı tekrardan farklı olarak yaratıcı-yenilikçi bir özellik taşır. Yaratıcı-yenilikçi tekrar, anlamını performatif eylemde her bir tekrarın bir öncekine atıfla ama bir öncekinden farklı olarak ilerlemesinden alır.

$\mathrm{Bu}$ durumda performatif, tekrar eden her pratikte değişimin de zorunlu olduğu çıkarımını yapmayı olanaklı kılar. Tekrarların hiçbirinin bir öncekiyle aynı olmaması, anlamın iletilirken değiştiğine işaret eder. "Performatiflik tekil ve kasti bir 'edim' olarak değil, aksine, yineleyici ve atıfsal bir pratik olarak anlaşılmalıdır” der Butler (2014: 8). Her pratik bir öncekine atıfla var olduğu için eylemlerin referans aldığ̣ orijinal bir öz yoktur. Butler'ın toplumsal cinsiyetin orijinali olmadığına yönelik iddiası böylece netleşir. Vurgulamaya çalıştığı şey sadece cinsiyette değil, doğal gibi görünen her şeyde var olduğu düşünülen özün imkânsızlığını görünür k1lmaktır.

Öte yandan Butler'ın performans ve performatif ayrımı, performansın önemini reddetmeyi gerekli kılmaz. "Performatif işlev ve performans aynı anlama gelmemekte ama birbirlerini besleyebilmektedir" (Nuhrat, 2018: 263). Her ne kadar Butler'ın en önemli eseri sayılan Cinsiyet Belası'nda bu iki kavram 
arasındaki sınırı net bir şekilde çizmediği düşünülse de (Salih, 2002: 63), tartışmayı sonraki eserlerinde (özellikle Bela Bedenler'de ${ }^{4}$ ) derinleştirir ve tıpkı pek çok teorisyeni eleştirirken onlardan beslendiği gibi performans kavramını da kendi kuramı için yararlı ve etkili bir kavrama dönüştürerek kullanır. Yani Butler'ın performans kavramını da yaratıcı-yenilikçi tekrarla yeniden kullanıma soktuğu, performatifi performansa kıyasla kavramsallaştırdığı söylenebilir.

Butler, öznenin varlığını önceden varsayan performans ile varsaymayan performativiteyi birbirinden ayırırken bunun öznenin hiç olmadığı anlamına geldiğini değil, onun tam olarak bulmayı umduğumuz yerde olmadığı anlamına geldiğini ima eder (Salih, 2002: 45). Yani özneyi kuranın performatif pratikler olduğu fikri bu pratiklerden önce herhangi bir özne olmadığı çıkarımını yapmak için değil, öznenin sürekli inşasının, sınırlarının muğlaklığının, zemininin kayganlığının ve bu sürecin ucu açıklığının izlerini sürmek için yarar sağlar. Bu özne tartışmasında beden, inşanın gerçekleştiği bir mevki değil, öznenin oluşmasına olanak sağlayan bir tahribattır (Salih, 2002: 127). Bedenin kendisi de performatiftir, iktidar aracılığıyla somutlaşır. “Butler'ın Foucault'yu okurken altını çizdiği ve katıldığı şey, Foucault'ya göre bedenin ona doğal ve özsel bir cinsiyet fikri yükleyen bir söylem tarafindan belirlenmesinden önce cinsiyetli bir varlık olmadığıdır. Beden, söylem içinde ve iktidar ilişkileri bağlamında cinsiyetli bir varlık olma anlamını kazanır" (Direk, 2012: 71). Ayrıca Foucault "iktidarın yalnızca beden üzerinde değil, bedenin içinde de işlediğini öne sürer; bu iktidar hem öznenin sınırlarını çizer, hem de onun içine yayılır” (Butler, 2005: 88). Yani bedenin iktidardan, iktidarın bedenden ayrı düşünülemeyeceği fikri Foucault için olduğu kadar Butler için de geçerlidir. Butler, maddi bedenin varlığını çürütmez ama bu bedenin kurucu ve performatif söylem olmadan herhangi bir statüsü bulunmadığında 1srar eder (Salih, 2002: 80).

Butler'ın beden tartışması, Althusser yorumuyla derinleşir. Butler, bedenin nasıl maddeleştiğini ve bir töz görünümünü aldığını Althusser'in (2001) interpellation (çağırma) kavramına atıfla ele alır. Özne

\footnotetext{
${ }^{4}$ Kathi Weeks, Bela Bedenler kitabının Butler'ın Cinsiyet Belası kitabında sunduğu argümanların temel çizgilerinden kopuşu içeren bir kitap değil, onların netleştirildiği ve genişletildiği bir kitap olduğunu söyler (2013: 176).
} 
olma halinin verili bir şey olmadığı argümanını, bunun iktidarın çağrısıyla gerçekleştiği örneği üzerinden derinleştirmek için bu kavramı hatırlatır. Ona göre iktidar ve yasa hem özneyi inşa eden hem de onu tabii kılandır. İşte Butler'ın performatif dediği şey buradaki iktidarın çağrısıdır. Çünkü “bu çağrı bir şeyi saptıyormuş ya da önceden varolan bir gerçeği ifşa ediyormuş gibi görünür, fakat aslında ifşa ettiği gerçeğin imkânının koşulunu (faili, yasayı ihlal eden özneyi) kuran, oluşturan da odur aynı zamanda" (Direk, 2012: 76). Butler, bireyin boyun eğdirilmiş özne statüsüne girişini başlattığı için bu çağrının şekillendirici ve icra edici olduğunu söyler (2014: 173).

Butler bu tartışmasında hem özneleşme hem de tabii olma kelimelerinin aynı kökten geldiğine dikkat çekerek iktidarın ikili rolüne vurgu yapar. Dikkat çektiği bu ikili anlamın benzerini maddeleşme ve sorunlaşma (to matter) ilişkisi üzerinden beden tartışması için de kurgular. Ona göre bedenin madde olarak görülmesi onun bir süreçle maddeleşmiş olduğu anlamına gelir ve bu bedenin anlaşılırlı̆̆ına dair sorunlaşan bir şeydir (Butler, 2014: 50). Anlaş1lmaz bir mefhum olan beden bu sorunsal süreç olmadan maddeleşemez. Bu argüman bedenin ne tamamının ne de herhangi bir parçasının öylece verili bir şekilde bulunmadığını ima eder. Bedeni veya bedenin parçalarını kuran ve anlamlandıran, on(lar)a yönelik performatif söylemler tekrarı ve bu söylemlerle anlamını bulan beden ve parçalarının sürekli devam ettirdiği performatif eylemler dizisidir. Bu da bedenin cinsiyetinin, onun "erkek" veya "dişi” şeklinde kategorikleştirildiğinde performatif olarak kurulduğunu (Salih, 2002: 79) ima etmesinin yanı sıra, bu kategorikleştirmenin farklı bir performatif edimle değiştirilebileceğini de akıllara getirmesi açısından kritiktir.

Butler, üzerinde fazlasıyla durduğu performatif kavramı için yürüttügü beden tartışmasında onu yapıbozuma uğratmanın ne demek olduğunu, onları kullanmaya devam ederken altüst edip yinelemek ve iktidar araçları olarak kullanıldıkları bağlamdan çıkarmak olarak açıklar (2008: 63). Köçekliği de Butler'ın bu temel argümanları çerçevesinde (özellikle altüst edici tekrar üzerinden) okumak ve yapıbozuma uğratmak mümkün görünmektedir. Yazının bundan sonraki kısmında köçekliğin eşikte olma hali üzerinden anlam kaydırma, sınırları aşma, dönüştürme, karşı söylem yaratma gibi 
potansiyeller taşıdığı ileri sürülecektir. Köçekliğin performatif olduğu ve yıkıc1-aracı bir kimlik kategorisi olarak görülebileceği, yapılan saha çalışmasının desteğiyle tartışmaya açılacaktır.

\section{ARAŞTIRMANIN YÖNTEMI}

$\mathrm{Bu}$ çalışmada köçeklikle ilgili veri toplamak amacıyla çeşitli yöntemlerin dahil edildiği bir saha çalışması gerçekleştirilmiştir. Saha çalışması boyunca amaç, köçekliği köçeklerin ağzından dinlemek, performanslarını seyretmek, videolarını/çekilen filmleri izlemek ve bu sayede köçek performansını ve köçeklik kültürünü olabildiğince öğrenip anlamlandırmaya çalışmak olmuştur.

Görüşmeler Zonguldak, Bolu, Ankara, Çankırı, Bartın, Kastamonu ve Antalya'dan toplam on dört köçekle gerçekleştirilmiştir. ${ }^{5} 2017$ yılının ağustos ayında başlanan görüşmeler 2018 yılının eylül ayında tamamlanmıştır. Görüşülen köçekler arasında iki senedir köçeklik yapan da mevcuttur, yaklaşık kırk senedir yaptığını söyleyen de. Çoğu köçek ilkokul terk veya ilkokul mezunuyken, lise bitirdiğini söyleyen ve yüksek lisans mezunu olan birer köçek de çalışmaya dâhil olmuştur. Köçeklerin çoğu evli ve çok sayıda çocuğa sahiptir. Yaşları on altı ile elli iki arasında çeşitlilik göstermektedir. Görüşmelerin yanı sıra Zonguldak, Bolu, Ankara ve Bartın'da toplam sekiz canlı köçek performansı izlenmiştir. Bu gözlemler, köçek performanslarının görüşmelerde anlatılanlarla veya izlenen video/film görüntüleriyle sınırlı kalmaması açısından önemli veriler sağlamıştır. Ayrıca bu sayede köçeklerin takımlarıyla birlikte performans öncesi/sonrası hallerini ve seyredenlerle performans esnasındaki ilişkilerini olabildiğince geniş bir çerçevede gözlemleme firsatı yaratılmıştır.

Saha çalışmasının bir diğer bölümünü köçeklerle ilgili izlenen videolar ve iki Türk filmi oluşturmuştur. İnternette yayınlanmış ve online bir şekilde izlenebilir durumda olan köçek videoları, köçek performansının çeşitliliğini görebilmek açısından oldukça yarar sağlamıştır. Videoların yanı sıra yer yer betimlenecek olan iki Türk filmi ise Köçek (Nejat Saydam, 1975) ve Köçek (Cemal Şan, 2000)

\footnotetext{
${ }^{5}$ Yazı boyunca köçeklerin kimliklerini açık etmemek adına gerçek isimleri yerine kendi seçtikleri mahlaslar kullanılacaktır. Mahlas seçmede karara varamayıp bu seçimi araştırmacıya bırakan köçeklere memleketleri üzerinden isimler konması tercih edilmiştir (Bartınlı Köçek gibi).
} 
filmleridir. Bu filmler köçeklerin ve köçeklik geleneğinin nasıl temsil edildiğiyle ilgili birbirinden oldukça farklı iki örnek sunmuştur ve bu makalede öne sürülen argümanlara zengin bir altyapı sağlamada yardımcı olmuştur.

\section{KÖÇEKLER VE KÖÇEKLİK KÜLTÜRÜ}

Yapılan saha çalışmasından elde edilen veriler ışığında makalenin öne sürdüğü argümanları tartışmaya açmadan önce köçekliğin ve köçek performansının kısa tarihsel seyrine bakmak yararlı olacaktır. Literatürde köçeklik geleneğinin nasıl ortaya çıktığının tam olarak bilinmediği söylenir. Metin And, 16. yüzyıl İstanbul'u üzerine hazırladığı kapsamlı çalışmasında şöyle der: "Hristiyan şenliklerinin tersine Türk kadın ve erkekleri beraber dans etmezdi. Ayrıca yüksek mevki sahibi erkekler de dans etmezdi. Dans yalnızca kadınlara uygun görülürdü. Türk erkeği için en büyük erdem askeri başarıydı” (2015: 248). Bu durum günümüzden pek farklı olmayan bir şekilde dansın Osmanlı'da da kadınlarla ilişkili bir kavram olarak görüldüğünün işaretidir. Köçeklerin ve köçeklik geleneğinin o dönemde erkekler arası eğlencelerde dikkat çeken bir pratik olarak ortaya çıtığı düşünülebilir. Beşiroğlu, köçeklik geleneğinin İslam'ın etkisiyle ortaya çıkışına yönelik şu açılamayı yapar:

"Erkek meclisleri içinde Köçekliğin çıkışının sebeplerinin başında, kadının İslam içindeki konumu gelmektedir. Çok zengin eğlence kültürüne sahip olan ve İslamiyetin kabulunden önce yaşamının her anında olduğu gibi eğlencede de kadın erkek birlikte olan Türk toplumu, İslamiyetin kabulü ve beraberinde gelen kültürle bu değeri ayrı ayrı yaşamaya başlamıştır. $\mathrm{Bu}$ ayrılık özellikle erkekler arasında yapılan eğlencelerde bu açığın kapatılması amacıyla önce taklidi olarak başlatılmış, daha sonra nitelik değiştirip cinselliği çağrıştıran işlevlere bürünmesine de neden olmuştur” (Beşiroğlu, 2006: 119).

Koçu'nun belirttiğine göre tarihi kaynaklarımızda İstanbul köçeklerinden bahseden en eski eser 17. yüzyılda yazılmış olan Evliya Çelebi Seyahatnamesi’dir (2015: 54). Yalur, “köçekler, on dokuzuncu yüzyıl ortalarına kadar - harem ve 'hoşgörü düzeni’ gibi - Batı kaynaklarında adı geçen Osmanlı simgelerinden birisi gibidir" der (2013: 68). İlk olarak saray eğlencelerinde ortaya çıktığı düşünülen bu geleneğin yayılmasıyla “İstanbul'un çeşitli yerlerinde ve bazı kahvehanelerde de sürekli olarak köçekler 
bulunur, raks seyretmek isteyenler buralara da giderdi” (Sevengil, 2014: 124). Osmanlı'nın ilk dönemlerinde dans edenlere cinsiyet ayrımı gözetmeksizin genel olarak çengi dendiği; ancak daha sonra çenginin sadece kadın dansçılar için kullanılır olduğu, erkek dansçılara ise köçek, tavşan, tavşanoğlan, rakkas gibi isimler verildiği pek çok kaynakta geçer (Beşiroğlu, 2006: 112; And, 2014: 29; Oksaçan, 2015: 132-3; Ünlü, 2006: 228). Bu gelenekler zamanla zayıflamış olsa da günümüzdeki zenne gibi türlerin temelinde bu geleneklerin etkisi olduğu düşünülebilir.

Daha önce belirtildiği gibi dansın (ve özellikle köçekliğin) erkeklik performansıyla arasındaki uyuşmazlık, binlerce y1llık ataerkil tarihte erkek bedeninin her zaman kadın bedeninden üstün görülmesinden ve bir erkeğin bedenini kadın gibi kullanmasının hem kendi erkekliğini lekelemesi hem de diğer erkeklerin erkekliklerini tehdit etmesi riskini taşıyor olmasından kaynaklanır. Ancak Yalur'un açıklaması, bu tarz kategorilerin toplumdan topluma değişebildiği gibi tarihsel olarak da değişebildiğini vurgulaması açısından dikkate değerdir:

"Metin And, Orhan Koloğlu, Reşat Ekrem Koçu gibi Osmanlı tarihini özel duyarlılıklarla ele alan tarihçiler, yaşına bakmaksızın köçek icrasını 'kadınsı' olarak tanımlamış ve dolayısıyla sadece kadın taklidi yaptıklarını ileri sürmüş olsalar da, Batılı kadın/erkek cinsiyet kategorilerinin ve stereotiplerinin modern öncesi Osmanlı toplumu ve kültüründe aynı şekilde hâkim olduğu düşünerek hareket etmek bir hata olabilir. Osmanlı kültürü ve sanatında kadın/erkek kategorilerinin keskin bir şekilde belirginleşmesi daha çok on dokuzuncu yüzyıldaki Batılılaşma, modernleşme ve kapitalist dünya ekonomisine eklemlenme sürecinde gerçekleşmiş bir şeydir” (2013: 81).

Köçeklerin kadınları taklit etmiyor olabileceklerine yönelik bir başka argümanı da Aksoyak ileri sürmüştür. Aksoyak, Eski Yunan ve özellikle eski Roma'dan beri Doğu'nun güzellik algılayışının cinsiyete bağlı olmadığını vurgulamış, bu algılayışa göre kadın ya da erkek güzelliğinin aynı derecede etkileyici ve meftun olunası bir şey olduğunu belirtmiştir (2009: 129). Farklı bir yaklaşımla Kılıç da köçeklerin kadın tipini canlandırmadıklarını, fiziksel görünümleri ve hareketleriyle bir erkeğin erkek kimliğinde kadınsı tavırlar sergilemesini temsil ettiklerini belirtmiştir (2009: 362). Bu yaklaşımlarla 
bakıldığında köçekliğin toplumsal cinsiyet ve güzellik algısının günümüzden oldukça farklı olduğu bir zamanda ortaya çıktığını ve erkek bedeni ile zamanın estetik anlayışının bir arada ilerlediği bir gelenek olarak yayıldığını söylemek mümkündür.

Güzellik anlayışının köçeklik için ne kadar kritik önem taşıdığı, köçek olmak için eğitilecek kişilerin kimlerden seçildiğine bakıldığında da görülebilir. Osmanlı'da köçeklik için eğitilecek çocukların “eli yüzü düzgün, güzel ve vücutlarının biçimli olması” gerektiği belirtilir (Kılıç, 2009: 356). Sevengil, bu çocuklar için "güzel erkek çocuklar arasından seçilir, bunlara özel surette meşkhanelerde müzik eğitimi yaptırılır, makamlar ve ezgilerle yakınlıkları sağlanır, kendilerine ayrıca raksın da tüm incelik ve kuralları öğretilirdi” der (2014: 122). Koçu ise bir oğlanın köçek olabileceğinin ayaklarından anlaşıldığını ve ayakların irikıyım, uzun parmaklı, iri topuklu ve bilekleri ince olmasının şart olduğunu belirtir (2015: 54). Öte yandan köçeklerin dansçı rollerinin sakalları çıkıp, dişi görünümünden çıkmaya başladıkları anda bittiği, bundan sonra hayatlarına müzik gruplarında çalgı çalarak veya şarkı söyleyerek devam ettikleri söylenir (Beşiroğlu, 2006: 119).

Günümüze yaklaştıkça köçeklik geleneğinin iyice zayıfladığı görülür. Bunda hem köçeklerin toplumsal düzeni bozduğu ve modernleşme sürecinde Batının normlarına uymadığı yönündeki düşünceler, hem de ikili cinsiyet rejiminin ve heteronormatif cinselliğin güçlenmesi etkili olmuştur (Haynes, 2014; Mansbridge, 2017, Avc1, 2017). Yine de İstanbul'un eğlence hayatına yayılan köçeklik geleneğinin Anadolu'ya da yayılmasının etkisiyle bazı köçekler bu geleneği günümüze kadar sürdürmüştür. ${ }^{6}$ Karataş'ın belirttiğine göre köçekler 19. yüzyılda İstanbul'dan özellikle Batı Karadeniz Bölgesi'ne yerleşip varlıklarını burada devam ettirmişlerdir (2012: 294). Erkan da benzer şekilde Zonguldak, Kastamonu, Bolu, Tokat, Kırşehir, Safranbolu ve Merzifon'da köçeklik geleneğinin halen yaşadığını veya yakın tarihe kadar izlerinin mevcut olduğunu belirtmiştir (2011: 229).

\footnotetext{
${ }^{6}$ Kaynaklarda köçekliğin 1857 yılında çıkarılan bir kanunla yasaklandığı belirtilir (Beşiroğlu 2006; And 2014; Oksaçan 2015). Ancak yasaklamalara rağmen köçekler Anadolu'da düğün ve eğlencelerin vazgeçilmez bir öğesi olarak varlığını sürdürmüştür (Oksaçan 2015: 138).
} 
Günümüzdeki köçeklik çok daha farklı dinamiklerle ilerler. Örneğin artık köçeklerin beden güzelliği ön plana çıkmamaktadır. Sakal, bıyık gibi "erkeksi” formlar köçekliğe engel teşkil etmemektedir. Yetişkinliğe geçiş köçekliğe dezavantaj oluşturmamakta, aksine deneyime işaret etmesi açısından önem arz etmektedir. Sadece parlak yüzlü oğlan çocukları tarafından değil, her yaştan erkekler tarafından gerçekleştirilmektedir. Baba-oğul olmanın daha da önem arz ettiği usta-çırak ilişkileri oldukça kıymetli görülmektedir. Ve öncelikli amaçları atalardan yadigâr bu geleneği sürdürmek, insanları eğlendirmek ve para kazanmaktır.

Dolayısıyla köçekler her ne kadar kimilerince nasıl ortaya çıktıkları üzerinden "kadın kılığına girmiş erkek dansçılar" olarak açıklansa da hem Osmanlı'da dönemin tam olarak keskinleşmemiş cinsiyet kategorileri sebebiyle hem de günümüzde köçekliğin değişen dinamikleri nedeniyle aslında köçekleri bu tanım üzerinden açıklamak oldukça güçtür. Köçeklerin sergilediği performans, bugün hâlâ normatif erkeklik değerlerine uygun görülmediği için onların erkekliklerinin ötesine geçmekte, ancak bu öteye geçiş kadınları taklit etmiyor olmaları sebebiyle kadınlıkla da ilişkilenmemektedir. Bu da köçekliğin günümüzde cinsiyet ikiliği üzerinden ele alınması yerine mevcut cinsiyet algısını ve rollerini aşan performatif bir icra olarak okunabilmesine olanak sağlar. Bu okuma, köçek performansının eşiktelik yarattığ1 ve köçekliğin liminal bir etkinliğe işaret ettiği argümanlarıyla tartışmaya açılabilir.

\section{EŞİKTE DANS: LİMINAL BİR ETKİNLIKK OLARAK KÖÇEKLİK}

Tiyatro kuramcısı Victor Turner tarafindan geliştirilen liminal kavramı, özellikle performans çalışmaları alanında gündelik hayat ile performans arasındaki ilişki üzerine düşünme fırsatı sağlamıştır. Carlson'ın belirttiği gibi liminal etkinlikler, Turner tarafından normal kültürel işlemlerin "yapı"sına ters düşen bir “karş1-yapı” olarak kavramsallaştırılmıştır (2013: 43). Atay’a göre Turner ilgisini “Levi-Strauss'un 'ikili karşıtlıklar'ının ara kesitinde toplar ve insan gerçeğini orada, onların geçişliliğinde ve bireşiminde bulur" (2012: 129). Liminal etkinlikler, gündelik hayat aktivitelerinin alternatiflerine ve bu alternatiflerle birlikte geçici ihlallere işaret eder. Performans da bu anlamda liminal ve özgürleştirici olur (Heuvel, 1992: 49). Dolayısıyla performansların liminal etkinliklere işaret ettiği, onların bizi 
gündelik yaşamın dışına firlatması üzerinden anlaşı1ır olur. Performans tam da bu yüzden değer ve anlam kazanır (Candan, 2010: 15).

Bu özelliğiyle liminal etkinlikler, gündelik aktivitelerden sökülüp alınmış bir uzam yaratır (Carlson, 2013: 43). Bu uzam, bu yazıda köçek performansı tarafından yarattı̆̆ savunulan alanı da temsil eder. Köçeklerin gerçekleştirdiği dans, kendine has özelliğini gündeliğe ters düşen yapısından alarak liminal bir etkinliğe, yani eşikteliğe işaret eder. Bu başlık altında, yapılan saha çalışmasının da desteğiyle köçeklerin ve köçeklik kültürünün liminal bir etkinlik olarak okunabileceği dört durum üzerinden ele alınacaktır: Köçeklerin köçek olma hali esnasında ne erkek ne kadın olarak görülebileceği, köçek danslarının ve kıyafetlerinin ne erkeksi ne kadınsı olarak okunabileceği, köçeklerin performans esnasında bazen özne bazen nesne konumunda olabildikleri ve köçekliğin hem doğuştan hem sonradan kazanılan bir yetenek olarak görülebildiği.

\subsection{Ne Erkek Ne Kadın}

Köçekliğin erkekler tarafından yapılıyor olması, bu performansın bir erkek(lik) performansı olduğu anlamına gelmemelidir. Çünkü köçeklik yapan erkekler, erkekliği köçeklik performansından önce ve sonra icra ederler. Aynı şekilde köçeklerin performans esnasında kadınlara atfedilen kıyafetleri giymeleri ve dans ediyor olmaları, köçek performansının bir kadın(lık) performansı olduğu anlamını da taşımaz. Köçekliğin sergilendiği an, öncesi ve sonrasından bağımsız olarak bambaşka bir oluş ve inşa sürecine işaret eder. Köçeklik, eşikte olma halini öncelikle performans esnasında cinsiyet kategorilerinin ötesine geçmekle kazanır.

Köçeklerle yapılan görüşmelerde cinsiyetle ilgili sorulan sorular, onların erkeklik ve babalık algıları üzerinden şekillenmiştir. Köçeklerin erkeklik ve babalık rollerinin kendi köçeklik pratiklerinde ne derece etkili olduğu öğrenilmeye çalışılmıştır. Bu yüzden cinsiyet üzerine yapılan sohbetler daha çok babalık rolleri ve "kadınlar neden köçek olamaz?" sorusu üzerinden ilerletilmiştir. Sahaya çıkılmadan önce, köçeklerin bu konudaki paylaşımlarının bu yazıdaki "köçekliğin erkek veya kadın olma halinden bağımsız olduğu” argümanıyla örtüşmeyeceğine yönelik kaygılar mevcut olsa da görüşülen köçeklerin 
çoğunun yaptığı paylaşımların bu argümanı desteklediği görülmüştür. Köçeklerin hemen hemen hepsinin ilk vurguladığı şey, köçekliğin erkeklikle veya kadınlıkla herhangi bir alakası olmadığı yönündedir. Hatta bu soruları yersiz bulan bile olmuştur:

"Erkeklik ne alaka şimdi? O başka, bu başka." (Bolulu Köçek 3)

Görüşülen köçeklerin hepsi kendini erkek olarak tanımlayan kişilerdir. Ama mesele köçeklik ve erkeklik ilişkisine geldiğinde köçekliğin erkeklikle "ayrılmaz" ilişkisinden değil, bu iki kategorinin birbirlerinden alakasız ve bağımsız kategoriler olduğundan bahsetmişlerdir. Bu paylaşımların altında kendi erkekliklerine laf kondurmamak olduğu düşünülebilir elbette. Ama araştırmanın odak noktası onların gündelik hayatlarındaki varoluşları değil, performans esnasındaki köçeklik halleridir ve tam da bu halin köçekler tarafından dahi erkeklikten bağımsız düşünülüyor olması, yazının argümanını destekler niteliktedir.

"Hepimiz erkeğiz, o ayrı. Ama köçeklik başka bir şey. Bir gelenek, bir iş. Erkekliğimizle açıklanamaz bu. Hepimiz erkeğiz. Evet kadından köçek olmaz ama ondan da dansöz olur mesela. Ha giyer kıyafetleri, köçeklik de yapar belki ama atalarımızdan öyle görmemişiz biz, o yüzden yadırganır. Kabul görmez.” (Çılgın Köçek)

“Sen de erkeksin ama küpen var mesela. Bu seni kadın mı yapar? ‘Karı gibi’ diyen vardır illa ki ama sen erkeksin sonuçta değil mi? Belki şöyle böyle derler, marjinal falan derler en fazla. Ama bize onu da demezler, diyemezler. Çünkü geleneğimizde var bu. Erkeklik kadınlık olayı değil. Köçeklik bu. Babalarımız dedelerimiz yapmış. Küpe takmak yok mesela.” (Genç Köçek)

Köçeklerin performans esnasında erkek ve kadın olma halinden bağımsız olarak sadece köçek olmaları üzerinden okunabileceğine yönelik argüman, Nejat Saydam'ın Köçek (1975) filminde temsil edilen köçeğin deneyimi üzerinden de desteklenebilir. Çift cinsiyetli olmasıyla ne erkek ne kadın ya da hem erkek hem kadın olma durumunun gündelik hayatta gerçek bir örneği olan Caniko (Müjde Ar), köçekliğin kadın/erkek olma halinden bağımsız olmasının da sembolik bir örneğidir aslında. Çünkü ameliyatından önce Caniko her ne kadar kendini erkek olarak tanımlıyor ve bir erkeklik performansı 
sergiliyor olsa da sahip olduğu bedensel özelliklerden dolayı cinsiyetinin muğlaklığı sık sık vurgulanır ve bu sebeple aşağılamalara maruz kalır. Ama öte yandan Caniko'nun cinsiyetinin muğlaklığının, onun köçekliğini etkilemediği görülür. Her ne kadar geleneksel kıyafetler giymese de sokaklarda çalgıcılar eşliğinde dans edip para kazanan Caniko filmde hep bir köçek olarak anılır. Yani Caniko’nun gündelik hayattaki cinsiyet performansının bile aslında köçek performansına bir etkisi yoktur. Köçek olma hali, öncesi ve sonrasından bağımsız olarak, performans esnasında cinsiyet tanımamaktadır.

\subsection{Ne Erkeksi Ne Kadınsı}

Yapılan görüşmelerde köçekliği cinsiyetten bağımsız bir şekilde ele alan paylaşımlar, benzer şekilde performans esnasında gerçekleştirilen dansın, giyilen kıyafetlerin ve takılan aksesuarların da cinsiyet kategorilerinden bağımsız olduğuna vurgu yapar nitelikteydi. Köçeklerin hepsi görüşme esnasında köçek kıyafetleri ve dans koreografileri için kullanılan "kadınlara atfedilen kıyafetler / kadınlarla özdeşleştirilen danslar” şeklindeki ifadeleri reddetmiştir. Köçek kıyafetinin sadece köçeklerin giydiği bir kıyafet, köçek dansının ise sadece köçeklerin yaptığı bir dans olduğunu özellikle vurgulamışlardır. Yani kıyafetler ve danslar bu sefer "erkeksi" ve "kadınsı" kategorilerinden bağımsız olarak yine sadece köçekliğe özgü olmaları üzerinden değerlendirilmiştir.

Köçek kıyafetinin sadece bir köçek kıyafeti olduğuyla ilgili paylaşımlarda bulunanlardan Usta ve Angaralı, bu argümanlarını kadınların bu kıyafetleri giymediklerine yönelik yaptıkları vurguyla şekillendirmiştir:

"İlgi de yok eskisi kadar. Halbuki bunun erkek olmamızla alakası yok ki. Bunlar da kadın kıyafeti değil. Sen hangi kadında gördün bu kıyafetleri. Ben hiç görmedim bunları giyen kadın. Evet etek ama farklı, köçek kıyafeti bunlar. Sadece köçekler giyiyor.”(Usta)

"Nasıl ki diğer yöresel oyunların kendine has kıyafetleri var, şalvar gibi mesela, bizimki de bu. Onları gördüğünde hangi yöredir, nedir, ne değildir anlarsın. Bunları gördüğünde de köçek olduğunu anlarsın. Yolda beni böyle görsen kadın mı sanırsın? Yoo. Köçek der geçersin.” (Angaral1) 
Görüşülen köçeklerin hepsinin farklı şekillerde dillendirdiği bu yaklaşım, köçeklerin performans esnasında sergiledikleri hareketler için de geçerliydi. Görüşmelerde bu mesele daha çok "göbek atma" söylemi çerçevesinde ele alınmıştır. Göbeğin cinsiyetlendirilmiş bir kavram olduğundan, “dansöz”lüğe işaret ettiğinden ve oryantalist bir genellemeyle "doğulu kadın" algısını şekillendiren unsurları düşündürdüğünden bahsetmek mümkündür (Antmen, 2017: 106). Bu açıklama, köçekliğin tarihsel kökeni hatırlandığında göbek atmanın köçeklerin danslarında neden büyük yer tuttuğunu da açıklar niteliktedir. Ancak daha önce değinildiği gibi köçekliğin tarihsel seyrinde yaşanan değişimler ve yeni algılar, köçeklerin göbek atmalarının bugün "doğulu kadın”1 çağrıştırmamasında veya köçekliğin dansözlükle ilişkilendirilmemesinde rol oynar. Göbek atmak hâlâ "kadınsı" olarak görülür belki ama bir köçek göbek attığında bu kadın dansı değil, köçek dansı olur. Seyredenler de "erkeğe bak, göbek atıyor" demez, "köçeğe bak, göbek atıyor" der. Çünkü göbek atmak cinsiyet kategorileri bazında sadece kadınlara atfedilmişken, bu yazıda bu kategorilerden bağımsız olduğu savunulan köçek kategorisinin de bir özelliği olmuştur artık.

Görüşme boyunca köçekliği hakkını vererek yapmak gerektiğine yönelik düşüncelerini sık sık vurgulayan Baba Köçek, performans esnasında gerçekleştirilen koreografinin başarılı bir şekilde gerçekleştirilmemesinin o dansı köçek dansından çıkarabileceğine ve bu durumun köçeklik kültürüne olumsuz etki edeceğine değinmiştir. Bu yorumu yaparken verdiği örnek, köçeklerin dansıyla dansözlerin dansı arasındaki sınıra işaret ediyordu:

“Çakma köçekler türedi, türemez olur mu? Burada özellikle. Küçük şehirlerde, işte Devrek’tir Karabük'tür, Bartın'dır, kim köçektir kim değildir bilinir. Ama bura öyle mi? Büyükşehir. Öyle herkes herkesi tanımaz. O yüzden ya tam eğitilmemiş ya hiç öğrenmemiş. Ha ya da beceriksiz (gülüyor). Birinden izliyor birkaç kere, sonra ‘ben de köçek oldum’ deyip başlıyor orada burada dans etmeye. Edemiyor tabi ki. Ya zıplıyor oradan oraya ya da iyice böyle dansöz gibi, kıvıra kıvıra bir şeyler... Bunlar türedikçe bize de laf geliyor. Sonra tabi yasaklanır orada burada. İnsanlar da çağırmaz olur. Dansöz müyüz biz?” (Baba Köçek) 
Dolayısıyla "köçek gibi giyinmek / köçek gibi dans etmek" ile "kadın gibi giyinmek / kadın gibi dans etmek” arasındaki sınırın köçekler için oldukça önem arz ettiğini söylemek mümkündür. Dansın ve hatta kıyafetlerin ikinciye, yani "kadın gibi giyinmek / kadın gibi dans etmek"e kaymaması, o performansın iyi bir köçek performansı olmasını sağlaması açısından oldukça etkilidir. Bir köçeğin giydiği eteğin gelenekselleşmiş köçek eteğinden farklı olması veya yaptığı dansın oryantale veya farklı dans türlerine kayması, o kiş̧iyi başarısız bir köçek yapacağı gibi performansı gerçekleştiren köçeği de köçek kategorisinden çıkarma ve kadın kategorisine sokma "riski" taşır. Öte yandan performans esnasında köçekliğe uymayan eril hareketler sergilemek de iyi karşılanmaz ve performansı sekteye uğratır. Yani dans ve kıyafet üzerinden köçeklik geleneğini açıklamada cinsiyet kategorileri bir kez daha işlevsiz kalır. Köçeklik, kadınsılıktan ve erkeksilikten bağımsız olarak ve onlardan uzak durarak ne erkeksi ne kadınsı olma haliyle yine ayrı bir kategoriye işaret eder.

\subsection{Bazen Özne Bazen Nesne}

Köçeklerin performans esnasında özne konumunda mı yoksa nesne konumunda mı oldukları da muğlaktır, değişkendir. Köçek performansı sadece köçeklerle (ve köçek takımlarıyla) değil, her performansta olduğu gibi seyirciler başta olmak üzere pek çok etkenin varllğı̆yla gerçekleşir (Barutçu, 2020). Bu performansta öncelikle köçeğin özne olduğu düşünülebilir ve bu özne, öznelik özelliğini tam da performans esnasında, o performans devam ettiği sürece sürdürür. Yani sabit değildir, sürekli oluş halindedir. Ama performansa seyredenin gözünden bakıldığında, köçekler bu performansın bir nesnesi konumuna geçerler. Çünkü bu sefer köçekler oynayandan öte oynatılandır, izlenendir, seyredilendir. Bu değişkenlik, seyircinin etkisi göz ardı edildiğinde dahi köçeklerin bedenleriyle olan ilişkileri üzerinden tekrar ortaya çıkar. Köçeğin performansı oluş halinde bir özneye işaret ederken, köçeğin bedeni hala bir nesne konumundadır. Yani kişiyi bir özneleşme sürecine sokarak onu köçek yapan şeylerden biridir bedeni. Tıpkı giydiği kıyafetler, sergilediği hareketler, o esnada çalan bir çalgıcı, çalınan bir çalgı, bir müzik ya da oturan/oynayan/para atan bir seyirci gibi.

Beden performansı, oluş halindeki öznenin bir ön koşulu olarak işler. Öznenin performans esnasında bedenin de aracılığıyla inşa sürecini yaşadığg argümanı, öznelerin sabit olmayıp değişken ve çoklu 
olduğu fikrini de anlaşılır kılar. Çünkü bir performans (ve asla tamamlanmayacak özneleşme süreci) bittiğinde başka bir performans başlar ve yeni bir özne inşa sürecine girilir. Bu sebeple köçeklik ve erkeklik aynı anda icra edilemez ya da bu yüzden köçeklik ve erkeklik aynı bedende farklı zamanlarda icra edilebilir. Her bir performansta oluş halinde olan özne, aynı zamanda Hegelci tabirle "kendi olma süreci” olarak işler (Callinicos, 2013: 90). Köçekler de kendi olma, yani köçek olma sürecini köçeklik performansları aracılığıyla yaşar.

Bu yaklaşımların tersine köçeklerin sadece birer özne, hatta tamamlanmış bir özne ve bir töz olabileceği fikri, herhangi bir köçek performansı izlendiğinde zaten kolaylıkla yıkılır. Pek çok köçek performansı, performans esnasındaki konumların kayganlığını ve değişkenliğini açık bir şekilde gözler önüne serer. $\mathrm{Bu}$ çalışma dahilinde izlenen videolardan ${ }^{7}$ ve canlı performanslardan ${ }^{8}$ biri bu duruma iyi birer örnek olarak gösterilebilir.

Yaklaşık dokuz dakikalık bir köçek performansı içeren videonun öncelikle tamamı izlenmeyip sadece ilk ve son dakikalarına bakılırsa, performansın iki köçeğin dansıyla başlayıp yine iki köçeğin dansıyla bittiği görülür. Videonun başı ve sonu izlenmeyip doğrudan ortalarına (6:16-7:44 arası) denk gelinirse, bu sefer köçeklerin değil sivil kıyafetli iki erkeğin köçek dansı yaptığı görülür. Videonun tamamı izlendiğinde ise bu rol geçişlerinin nasıl öznelerin (veya nesnelerin) sınırlarının kayganlığını temsil ettiği görülmüş olur. Performans iki köçeğin dansıyla başlar ve bu bir köçek performansıdır. Daha sonra aralarına seyircilerden biri katılır ve köçeklerden biri dansı bırakıp oturarak seyirci konumuna geçer. $\mathrm{Bu}$ esnada devam eden performans hâlâ bir köçek performansıdır. Bir süre sonra bir seyirci daha sahnede belirir ve ikinci köçek de elindeki zilleri bu kişiye vererek kenara çekilir. Artık sahnede iki "seyirci" oynamakta, videoda artık görünmeyen iki "köçek" ise muhtemelen seyirci olarak onları izlemektedir. Yani sahnede artık hiç köçek yoktur ama o an süren performans hâlâ bir köçek performansıdır. Oynayan kişiler videonun sonuna doğru yerlerine oturur ve sahnede yine köçekler belirir. İster köçeklerin ister

\footnotetext{
7 "Köcek", https://www.youtube.com/watch?v=n-fb1WIp2Og Son erişim: 01.04.2020

${ }^{8}$ Zonguldak Kozlu'da gelin evi önü, 02.09.2017
} 
seyircilerin gözünden bakılsın ve hangisine özne hangisine nesne denirse densin, konumların kısa bir video süresince nasıl yer değiştirdiği ve öznelerin/nesnelerin nasıl birbirine girdiği açıkça görülmüş olur.

Zonguldak'ta seyredilen canlı köçek performanslarından biri de benzer bir durumu yansıtır. Bu performans da iki köçekle başlamıştır ama bu sefer iki köçekle değil, iki seyirciyle bitmiştir. Bu örnekte performansın sonlarına yetişen biri köçekleri değil, köçek olmayan iki kişiyi köçeklik yaparken görmüş olacaktır. Köçeklerle başlayan performansta performans süresince özne/nesne ve seyreden/seyredilen konumları oradan oraya kaymış, performans en son müziğin bitmesi sonucunda o an dans eden iki seyircinin durmasıyla son bulmuştur.

Dolayısıyla köçeklerin tamamlanmamış ve inşa halinde bir özne olarak köçek olma halini performans süresince deneyimlemesinin, köçek olmama halini ise performans öncesi/sonrası yaşamasının yanı sıra, performans esnasında da bu ve benzeri konumların durağan olmayıp çoklu dinamiklerle ilerlediğinden ve akışkan olduğundan bahsetmek mümkün görünmektedir. Yani köçek performansının da aslında hiçbir konumun sabitliğine olanak tanımayan bir uzamı temsil ettiği söylenebilir.

\subsection{Hem Doğuştan Hem Kazanılmış}

Köçekliğin hem doğuştan gelen hem de sonradan kazanılmış bir yetenek olduğu düşüncesiyle de kendine ayrı bir konum edindiğini söylemek mümkündür. Köçek olmanın doğuştan geldiği fikri akla yatkın değilmiş gibi durmaktadır. Ancak köçekliğin sıkı bir eğitimle birlikte sonradan öğrenilen bir şey olduğunun düşünülmesinin yanı sıra, görüşme yapılan köçeklerin büyük çoğunluğu bu yeteneğin doğuştan da gelmesi gerektiğine yönelik paylaşımlarda bulunmuştur. Doğuştan gelene yapılan bu vurgu, aileden veya atalardan kalan kalıtsal bir yeteneğe veya öğrenmeye duyulan içten bir şevke işaret etmektedir. Görüşülen köçekler bu konudaki fikirlerini çoğunlukla "herkes köçek olabilir mi?” sorusu çerçevesinde yapılan sohbette dile getirmiştir.

"Doğuştan gelen bir şey. Allah tarafindan verilmiş bir şey. Herkese bir meslek verilmiş, bizimki de bu.” (Bolulu Köçek 3) 
“Asla olamaz. İçinden gelerek yapacak. Çekirdekten yetişmesi lazım, oyunları bilecek, adabı bilecek. İçinde onu taşımayan, çocukken bu iş için eğitilmeyen kişi yapamaz. İçinden gelmeli. Baba mesleği olması önemli. Tutup sen yaparsan eğreti durur, olmaz.” (Bolulu Köçek 1)

"Yok, kanında olması, bir yatkınlığı olması lazım. O zaman özümser, sade iş olarak görmez, sıkılmaz, kendini geliştirir, başarılı olur. Öyle doğacak, görerek büyüyecek.” (Çingen)

Köçeklerin bu dansa yatkınlığının doğuştan da gelmesinin şart olduğuna yönelik iddialar, bu geleneğin atalardan kaldığı, onlardan öğrenildiği ve sürdürüldüğü/sürdürülmesi gerektiği savunularıyla temellendirilmiştir. Örneğin Bolulu Köçek 1 ve Belalı'nın düşüncesine göre bir araştırmacı olarak ben, daha önce köçeklik yapmadığım ve dahası köçeklik geleneğinden gelen bir ailenin içine doğmadığım için çok iyi köçeklerden sıkı bir eğitim alsam dahi gerçek bir köçek olamazdım. Çünkü onlara göre has köçekler, köçekliğe doğduğu andan itibaren yatkın olan kişilerdi. Benim iyi bir köçek olabilmem için bu yatkınlığa sahip olmam gerekiyordu ve köçek olma isteği küçüklügümden beri içimde olmalıydı. Bunun için de babam başta olmak üzere büyüklerimin köçek olduğu bir ailede ve sosyal çevrede, kanımda köçekliği taşıyarak doğup büyümem şart görülüyordu.

Öte yandan böyle bir aile veya sosyal çevre içinde doğmuş olmak, görüşülen köçeklere göre iyi bir köçek olmak için tek başına yeterli değildir. Bu durum, köçeklik yeteneğini geliştirebilmek için doğuştan gelen bir avantajdır sadece. Köçek olacak kişinin aynı zamanda çocukluğundan itibaren çalışmaya başlaması ve büyüklerini sürekli izlemesi gerekmektedir. Yani doğuştan gelen yetenek, iyi bir baba/oğul veya usta/çırak ilişkisiyle tamamlanmalıdır. Köçeklerin belirttiğine göre bunu yapan kişiler daha çocuk yaşta büyüklerini bile geçip dikkat çeken iyi birer köçek olabilirler. Çalışma dahilinde izlenen videolardan biri bu paylaşımlara örnektir. ${ }^{9}$ Bir düğünde çekilen videoda, 10'lu yaşlarının başında bir köçeğin kendinden büyük başka bir köçekle karşılıklı oynadığı başarılı bir performansa şahit olunur. Videonun başlığı “düğünde dayısına kafa tutan minik köçek”tir.

9 "düğünde dayısına kafa tutan minik köçek", https://www.youtube.com/watch?v=dIluoq2niE8 Son erişim: 01.04.2020 
Doğuştan gelen bir yetenek ve istekle köçekliği öğrenmeye başlayan kişinin sıkı bir çalışma sürecinden geçmesi gerektiğine yönelik paylaşımlar, Köçek (Cemal Şan, 2000) filminin meşhur açılış sahnesiyle de örtüşmektedir. Film, bir çocuğun iç çamaşırlarıyla ve elinde ağır bir taşla müzik eşliğinde oynatılmasıyla başlar. Çocuğun yarı çıplak olmasının ve elinde ağırlık taşıyor olmasının sebebi, oynarken cam kırıklarının üzerinde yürüyor olmasıdır. Üstelik yavaşlarsa ayaklarına bir sopayla vurularak uyarılır. Sahnenin sonunda ayakları kanamaya başlayan çocuğun acı içindeki yüzü ekranda donar ve "köçek" yazısı belirir. Bu çocuk, büyüyünce başarılı bir köçek olan Hasan'dır (Talat Bulut). Ustası sayesinde böylesine sıkı bir eğitim alarak iyi bir köçek olan Hasan, tam da bu nedenle ustasına sonsuz saygı duyar ve onun tarafından kendisine emanet edilen Kemal'i (Tolga Çevik) iyi bir köçek olarak eğitmek için uğraşır durur. Kemal ise köçekliğin doğuştan olan kısmına sahipmiş gibi görünse de sonradan kazanılacak kısmı için gerekli emeği harcamaz ve köçeklikten gitgide uzaklaşarak film boyunca Hasan'la çatışır.

Öte yandan köçek geleneğinden gelen bir ailenin içine doğmayan, sadece sonradan aldığı eğitimle köçekliği öğrenen ve icra eden kişilerin varlı̆̆ından da bahsetmek gerekir. Örneğin görüşme yapılan köçeklerden Mersinli Köçek, yetişkinliğinde aldığı eğitimle ara sıra köçeklik yapan ve ailesinde başka köçek bulunmayan biridir. Ancak görüşülen diğer köçeklerin paylaşımlarına dayanarak bu kişilerin diğer köçekler tarafından "gerçek köçek değil” (Çingen), "iyi dans edemezler” (Bolulu Köçek 1 ve Bolulu Köçek 3), “adabıyla yapamazlar” (Usta ve Çılgın Köçek) gibi söylemlerle geleneğe zarar veren köçekler olarak yaftalandıklarını ve köçeklik geleneğinin dışında tutulduklarını söylemek mümkündür.

Kısacası "gerçek" bir köçek olabilmek için kişinin hem bu gelenek içinden bir ailenin veya sosyal çevrenin içine doğup bu geleneği kanında taşımasının, hem de çocukluktan itibaren sıkı bir eğitimden geçerek kendini eğitip köçekliği özümsemesinin beklendiği söylenebilir. İki durumdan birine sahip olmamak, başarılı bir köçek olmanın önünde büyük bir engel olarak görülmektedir. Yani köçeklik bu sefer iki ayrı kategoriyi kendinde aynı anda barındırmasıyla yine ayrı bir alana işaret etmektedir. 


\section{YIKICI-ARACI BİR KİMLİK OLARAK KÖÇEKLİK}

Yukarıdaki bölümde yazının ana argümanı olarak köçeklerin performans üzerinden ayrı bir alan (eşik) yarattığı ve bu yüzden bu performansın sadece köçeklik kategorisi üzerinden açıklanabilir olduğu fikri desteklenmeye çalışılmıştır. Bunun yanı sıra köçekler performans esnasında bazı sınırları yıktığı/aştığı gibi muğlak da olsa yeni bir kimlik yaratmış olurlar. Bu başlık altında bu argüman, yeni bir kimlik yaratmanın yeni normatif sınırlar çizme tehlikesi barındırma olasılığı göz ardı edilmeden temellendirilecektir.

Orta Doğu ve Asya'daki erkek dansçıları ele aldığı makalesinde Anthony Shay, erkek dansçıları ayrı bir toplumsal kategori olarak ele alır. Bu coğrafyalardaki erkek dansçıların her zaman cinselliğe açık kişiler olarak algılandığına dair örnekler vererek erkek dansçı kategorisinin kendine özgü karakteristik elementleri olduğu vurgusuyla argümanını destekler (2006: 140-1). Yalur ise köçekleri esas aldığ1 yazısında bu argümanı biraz daha ileri taşır ve köçeklerin kendi başına birer cinsel kimlik olarak düşünülebileceğini savunur. Çünkü ona göre köçekler ancak erkekler ve kadınlar arasındaki ayrımın ötesinde olmasıyla mümkündür (2013: 71). Köçekler ayrı bir toplumsal kategori veya ayrı bir cinsel kimlik olarak düşünüldüğünde, bu karakterlerini şüphesiz ki kendine has yıkıcı/yaratıcı özelliklerinden kazanır. Yani performans esnasında ne erkek ne kadın olmasıyla, ne erkeksi ne kadınsı olmasıyla, bazen özne bazen nesne olmasıyla, hem doğuştan hem kazanılmış olmasıyla ve bunlarla bağlantılı bir şekilde seyreden/seyredilen, oynayan/oynatılan, sergileyen/sergilenen gibi ikiliklerde yarattığı muğlaklıkla. Çünkü bunlar üzerinden köçeklik, kendisini açılamaya yarayabilecek bütün normatif kategorileri yerle bir ederek yeni bir alanda var olur. Bu var oluş, birer öz olarak görülebilen biyolojik cinsiyetler üzerinden düşünüldüğünde dahi yine normatif kimlikleri reddeden ve sarsan yapısıyla ve mevcut alternatif kimliklere uymamasıyla ayrı bir pratiğe işaret eder.

Köçek performansında beden ve arzunun bir arada işlediğini görebilmek, köçekleri ayrı bir toplumsal kategori veya pratik olarak ele almak adına önem arz eder. Aslında köçek kategorisi, performatif bir üretimle var olduğu için tamamlanmamış, muğlak, geçici ve istikrarsızdır. Özkazanç ve Ağtaş’ın belirttiği gibi performatif üretimde söz konusu olan şey, "verili bir öz veya bir kimlik gibi gömülü halde 
bulunan şeyin kendini dışa vurması, gizlediği hakikati bu defa açıktan icra etmesi, sergilemesi gibi bir şey değildir; tam tersine, böyle bir iç nüve veya töz etkisini üreten, ona hileli bir şekilde istikrar, tutarlılık veya süreklilik atfeden şey edimler, bedensel hareketler ve arzunun bir araya gelişidir” (2018: 3). Köçeklik ayrı bir kimlik olarak düşünüldügünde dahi bu kimlik sabitlenemez, kalıcılaştırılamaz. Çünkü beden ve arzunun bir aradalığıyla ilerleyen performans sona erdiği an, köçeklik de son bulur. $\mathrm{Bu}$ durumda köçekliği ayrı bir kimlik kategorisi olarak ele almak, sadece köçekliğin normatif kimliklere yönelik yıkıcı-aracı işlev görebilecek geçici bir pratik olabileceği argümanı için yararlıdır.

Köçeklik, geçici bir kimlik kategorisi olma özelliğini yukarıda detaylandırılan eşikte olma halinden ve varlığı sürekli olan özsel bir varoluşa işaret etmemesinden alır. Köçekliğin temel bir varlık veya bir öz olmayan ve performatif olarak inşa edilen bir kimlik olarak görülmesi, sabit ve değişmez kabul edilen başka kimliklerin de aslında performatif inşayla var olduğunu ve sürekli yeniden inşa edilebilirliğini açık etmesi açısından önemlidir. Bu yazıda köçekliğe bir potansiyel olarak atfedilen yıkıcı-aracı işlev buradan gelir. Buradaki yıkıcılık, cinsiyetler başta olmak üzere bütün kategorileri tamamen yok etme anlamını taşımaz. Sadece Butler'ın draglar için söylediği üzere yaygın varsayımları yapısöküme uğratmak için etkili bir model sunar (akt. Jagose, 2015: 107-8).

Köçek kimliğine atfedilen geçiciliği ve yıkıcı-aracı işlevi akılda tutmak oldukça önemlidir. Çünkü bu sayede köçeklik kimliğini performatif inşa ve eşiktelik üzerinden okumaya çalışırken bu duruma ters düşebilecek yeni bir kimlik savunusu yapma riskinin de önüne geçilir. Butler düşüncesinin bütün kimliklerin içini boşaltan çabası göz önüne alındığında, köçekleri ayrı bir kimlik olarak ele alıyor olmak gerçekten bir çelişki yaratıyor gibidir. Ancak kimlik denen şeyin, Butler'ın belirttiği gibi performatif olarak kurulan ifadelerden, dışavurumlardan ibaret olduğunu unutmamak gerekir (2010: 77). Kimlikler aslında genelleştirilemez, herkeste ayrıdır, biriciktir. Butler'ın karşı çıktığı asıl şey kimliklerin bütünleştirici etkisi ve bu bütünleştirmeyle kimliklere atfedilen güçtür. Bu yüzden amacı da bütün normatif kimlikleri sarsmaktır. Bu durumda köçekleri ayrı bir kimlik kategorisi olarak görmek aslında bir çelişki yaratmamaktadır. Aksine diğer kimliklerin de tıpkı köçeklikte olduğu gibi performatif bir inşayla kurulduğunu ortaya çıkarmayı ve bu kimliklerin içini boşaltmayı sağlar. Bu sebeple köçek 
kimliği, diğer kimlikler için yıkıcı-aracı bir işlev görebilecek geçici ve muğlak bir ifade olarak tanımlanmalıdır.

Fischer-Lichte, "edimsel olarak adlandırılan bedensel hareketler halihazırda varolan bir kimliği ifade etmezler, daha çok kimliği gerçek anlamda yaratırlar” der (2016: 41). Köçekler böylesi bir kimlik yaratımının iyi bir örneğidir. Köçek performansı, sahnelemenin “önceden varolan veya verili olan bir şeyin dışavurumu olarak değil, daha çok bir yaratım süreci olarak" tanımlanması gerektiğine yönelik fikri açık bir şekilde gösterir (Fischer-Lichte, 2016: 293). Yani Butler'ın kavramlarına geri dönmek gerekirse, tekrar üzerinden ilerleyen bir süreçtir bu ve her tekrar yaratıcı-yenilikçi bir özellik barındırır. Huizinga’nın vurguladığı gibi danslar da “tıpkı ona eşlik eden ve yöneten müzik gibi, tekrar sayesinde hayat bulmaktadır” (2017: 224). Köçekler, köçeklik kimliklerini performansın sürekli tekrarı üzerinden edinirler. Performansta aynı koreografiyi tekrarlama çabasına girilse dahi, Fischer-Lichte'in belirttiği gibi “sahnelemenin yarattığı olay sadece bir defalığına meydana gelebilir". "Bu eşsiz bir olaydır, çünkü bir oyuncu grubu farklı ruh halleriyle, keyiflerle, isteklerle, düşüncelerle, bilgilerle vb dolu belirli bir sayıdaki seyirci grubuyla yalnızca belli bir zamanda ve belli bir mekânda karşılaşır” (2016: 57). Sonuç olarak da "benlik, kendisini tekrarlayan performanslardan başka bir şey değildir ve her zaman, her seferinde kendisinden halihazırda farklı olur" (Colebrook, 2014: 57).

"Sahnelemelerde maddeselliğin performatif bir şekilde yaratılması orada tezahür eden her şeyin gerçekten vuku bulmasına yol açar; burada onlara ek olarak belli anlamların yüklenmesi bu durumu değiştirmez" (Fischer-Lichte, 2016: 289). Köçeklik performansında da mevcut kategorilerden bağımsız olarak köçek olma hali ayrı bir gerçeklik kazanır. Köçekliğin “göbek atan erkekler” veya "kadın kılığına girmiş erkekler" gibi anlamlarla açıklanmaya çalışılması bu gerçekliği değiştirmemektedir. Tam da bu sebeple, yazının da savunduğu gibi, köçeklik dışındaki diğer kategoriler köçekliği açıklamada yetersiz/işlevsiz kalmaktadır.

Görüşme yapılan köçeklerden Köçek Oğlu Köçek’in paylaşımı, bu yazıyı sonlandırmak için oldukça uygundur. Kimlerin köçek olup kimlerin olamayacağı ve köçek kıyafetlerinin toplumda nasıl algılandığı 
üzerine olan sohbetimizde konu cinsiyete ve cinsel yönelime de gelmiş, sorular karşısında Köçek Oğlu

Köçek önce net yanıtlar vermeye çalışmış, en sonunda şu cümlesiyle aslında bütün toplumsal kategorilerin altını oyan bir yorumda bulunmuştur:

“Aman kimin ne olduğu belli değil aslında, boş versene.” (Köçek Oğlu Köçek) 


\section{SONUÇ}

Bu yazıda köçekliğin performatif inşası üzerinden başka kategorilerle açıklanamayan ve bu kategorileri muğlaklaştıran yapısına odaklanılmış ve köçekliğin eşikte olma hali vurgulanmaya çalışılmıştır. Köçekliğin bu eşikteliği, erkek/kadın veya erkeksi/kadınsı gibi toplumsal cinsiyet kategorilerine sığmayan ve özne/nesne, doğuştan/kazanılmış, seyreden/seyredilen, oynayan/oynatılan gibi ikili kategorilerin sınırlarını yerle bir eden özellikleri üzerinden savunulmuştur. Bunun yanı sıra köçeklerin eşikte gerçekleştirdikleri performansın ayrı bir kimlik kategorisi ortaya çıkardığı iddia edilmiş ve bu kimliğin yaratıcı-yenilikçi tekrarlarla ve yıkıcı-aracı bir etkiyle var olduğu gösterilmeye çalışılmıştır.

Tüm bu özellikleriyle köçek performansı, liminal bir performans olarak okunabilmektedir. "Liminal performans, kurulu düzeni tersine çevirebilir ama hiçbir zaman yıkamaz" (Carlson, 2013: 43). Elbette ki köçek performansı da toplumsal düzeni yıkma gibi bir amaç taşımaz. Bu amacı taşımaması, köçekliğin bu yazıda vurgulanan eşikte olma hâlinin sürekliliğini göstermesi açısından önemlidir. Çünkü böyle bir amaçla eşikteliğini kaybetmesi, onun normatif düzenin yeni bir parçası haline geldiği veya ayrı ve yeni bir normatif kimliğe dönüştüğü anlamını taşır. Bu durum da şüphesiz ki köçekliğin yazı boyunca ele alınan özelliklerinin artık yok olduğunu gösterir. Dolayısıyla köçeklerin eşikteliğinin sürekliliğini vurgulamak, var olan normatif düzeni yok etme amacı için değil ama bütün kimlikleri sarsıp bu kimliklerin potansiyel eşikteliğini gösterme amacı için önem arz eder.

Köçekliğe yönelik bu tarz bir okuma, yüzyıllardır süregelen köçeklik geleneğinin gündelikteki bazı anlamları kaydırdığını da göstermektedir. Örneğin uzun etekler köçek performansında kadın eteği olmaktan çıkmakta ve köçeklerin kostümü haline gelmektedir. Ya da göbek atan bir köçek akıllara "Doğulu Kadın” imgesini değil köçeklik performansını getirmektedir. Yani Butlercı bir yaklaşımla bakıldığında bu gibi örneklerde köçeklerin performans üzerinden bazı kavramları yaratıcı-yenilikçi tekrarla yeniden kullanıma soktuğu rahatlıkla söylenebilir.

Son olarak bu yazının kendisinin de "köçek" kategorisini yaratıcı-yenilikçi bir tekrarla yeniden dolaşıma sokma girişiminde bulunduğunu söylemek mümkündür. Çünkü tarihsel gelişimi içerisinde köçekliğin 
kültürel tanımı, onun bu yazıda ortaya serilen özellikleri üzerinden şekillenmemektedir. Köçeklik, genellikle yüzeysel bir şekilde "kadın kılığında dans eden erkek" olarak tanımlanan bir gelenek olarak görülmekte ve bu tanım nedeniyle zaman zaman aşağılamalara ve yasaklamalara maruz kalmaktadır. Köçekliğin bu yazıda ortaya çıkarılmaya çalışılan özellikleri üzerinden ayrı bir kimlik kategorisi olarak okunması, bu yaygın algıyı dönüştürme ve "köçek"i yeni bir kullanıma sokma potansiyeli taşımaktadır. Yani köçekliğin performatifliğine ve eşikteliğine işaret ederken aynı zamanda bu tarz bir okumayla performatif siyaset gütmenin bir örneği de sunulmuş olur. 


\section{SUMMARY}

The relationship between masculinity and dance in Turkish society has always been problematic. One of the reasons is the fact that many types of dances are mostly identified with femininity except for the types dominated by "masculine" forms in the last few decades under the influence of Western countries such as hip-hop and break dance. Dancing can be seen as a threat for the construction of masculinity by men. Turkish culture, on the other hand, includes a tradition that is performed by dressing "like woman" and often performed by acting "feminine" and it still continues to exist in certain regions of Anatolia. The dancer who performs this traditional dance is called as köçek.

Köçeks represent the traditional dancer boys in Turkish culture who wear the clothes which are attributed to women today like skirt and fancy waistcoat. They first emerged in the Ottoman Palace as servants who provide the Sultan and establishment of the palace entertainment and this tradition survived until contemporary times as part of a wedding and celebration culture especially in the North-western region of Anatolia. Although it is still an important tradition in Turkey, the number of studies which analyze köçeks is very limited. This article titled as "Dance on Liminality, Performative Construction and Köçek as a Destructive-Mediating Identity" attempts to reread Köçek tradition with different perspectives. It argues that köçeks can be thought as a separate social category which cannot be explained by any other categories and as a practice which have a potential to destruct other identities. Köçeks create a space by their performances that breaks some binary-oppositions and transcends some categories. With its unique characteristics, this space refers to liminality. Köçeks' dances on liminality both destroy the normative categories and represent a new identity that is not in the borders of normativity. In addition, it is considered that the construction of this new representation through performance can provide some clues to see the social construction of all other (so-called normative) identities. In order to support these arguments, interviews were made with fourteen köçeks in different cities of Turkey, eight live performances were observed, and related videos/movies were analyzed.

With the findings obtained in the field study, it is revealed in the article that köçeks create a space during their performance by the representation of body and subject-in-progress specific to themselves. This 
space points to the liminality with its characteristics like being "neither this nor that", "both this and that", or "sometimes this sometimes that". These characteristics of dance on liminality show that köçeks produce a non-normative temporal category of identity while destroying some normative categories and having bilateral oppositions. It has been suggested that köçek as the category of identity is performative and indicates a destructive-mediating practice. Thus, with these arguments supported by the field work, this article has been an attempt to reread the category of köçek as a creative-innovative repetition. 


\section{KAYNAKÇA}

Aksoyak, İ. H. (2009). 17. Yüzyıldan Tescilli Bir Köçek: Behzat. Milli Folklor, 84, 127-29.

Althusser, L. (2001). Lenin and Philosophy, and Other Essays. New York: Monthly Review Press.

And, M. (2014). Başlangıcından 1983 'e Türk Tiyatro Tarihi. (4. Basım). İstanbul: İletişim.

And, M. (2015). 16. Yüzyllda İstanbul: Kent, Saray, Günlük Yaşam. (3. Basım). İstanbul: Yapı Kredi.

And, M. (2016). Oyun ve Bügü: Türk Kültüründe Oyun Kavramı. (4. Basım). İstanbul: Yapı Kredi.

Antmen, A. (2017). Kimlikli Bedenler: Sanat, Kimlik, Cinsiyet. (3. Basım). İstanbul: Sel.

Atay, T. (2012). Çin İşi Japon İşi: Cinsiyet ve Cinsellik Üzerine Antropolojik Değiniler. İstanbul: İletişim.

Avc1, M. (2017). Shifts in Sexual Desire: Bans on Dancing Boys (Köçeks) throughout Ottoman Modernity (1800s-1920s). Middle Eastern Studies, 53 (5), 762-781.

Barutçu, A. (2020). Köçek Performansında Bedensel Bir Aradalık ve Seyredenin Seyredilene Bakışı. Moment Dergi, 7 (2), 219-240.

Basetti, C. (2013). Male Dancing Body, Stigma and Normalising Processes. Playing with (Bodily) Signifieds/ers of Masculinity. Recherches Sociologiques et Anthropologiques, 44 (2), 69-92.

Beşiroğlu, Ş. Ş. (2006). Müzik Çalışmalarında 'Kimlik', 'Cinsiyet': Osmanlı'da Çengiler, Köçekler. Folklor/Edebiyat Dergisi, 12: 454, 111-28.

Burt, R. (1995). The Male Dancer: Bodies, Spectacle, Sexualities. London: Routledge.

Butler, J. (2005). İktidarın Psişik Yaşamı: Tabiyet Üzerine Teoriler. F. Tütüncü (Çev.). İstanbul: Ayrıntı.

Butler, J. (2008). Olumsal Temeller: Feminizm ve "Postmodernizm" Sorusu. Seyla Benhabib, Judith Butler, Drucilla Cornell ve Nancy Fraser (Der.), F. Evren Sezer (Çev.), Çatı̧̧an Feminizmler Felsefi Fikir Alışverişi içinde (s. 44-67). İstanbul: Metis.

Butler, J. (2010). Cinsiyet Belast: Feminizm ve Kimliğin Altüst Edilmesi. B. Ertür (Çev.). (2. Basım). İstanbul: Metis.

Butler, J. (2013). Kritik Queer. Sibel Yardımc1 ve Özlem Güçlü (Der.), Queer Tahayyül içinde, (s. 121148). İstanbul: Sel.

Butler, J. (2014). Bela Bedenler. C. Çakırlar ve Z. Talay (Çev.). İstanbul: Pinhan. 
Callinicos, A. (2013). Toplum Kuramı: Tarihsel Bir Baklş. Y. Tezgiden (Çev.). (6. Basım). İstanbul: İletişim.

Candan, A. (2010). Oyun Tören Gösterim. İstanbul: Norgunk.

Carlson, M. (2013). Performans: Eleştirel Bir Giriş. B. Güçbilmez (Çev.). Ankara: Dost Kitabevi.

Colebrook, C. (2014). Ne Kadar Queer'leşebilirsiniz? Teori, Normallik ve Normatiflik. KaosQueer+ Kaos Queer Çalışmaları Dergisi, Sayı 1, 53-62.

Davletov, T. B. (2017). Şaman: Doğa'nın Şifası Uyanınca. İstanbul: Asi Kitap.

de la Croix, H. ve Tansey, R. G. (1986). Gardner's Art through the Ages. (8. Basim). Harcourt Brace Jovanovich, Inc.

Direk, Z. (2012). Judith Butler: Toplumsal Cinsiyet ve Bedenin Maddeleşmesi. Zeynep Direk (Der.), Cinsiyetli Olmak: Sosyal Bilimlere Feminist Bakışlar içinde (s. 67-84). (3. Basım). İstanbul: Yap1 Kredi.

Erkan, S. (2011). Köçek Tipinin Uluslararası Kökeni Üzerine Bir Deneme. Ankara Üniversitesi Dil ve Tarih-Coğrafya Fakültesi Türkoloji Dergisi, 18 (1), 223-40.

Fischer-Lichte, E. (2016). Performatif Estetik. T. Acil (Çev.). İstanbul: Ayrıntı.

Fisher, J. ve Shay, A. (Der.), (2009). When Men Dance: Choreographing, Masculinities, Across Borders. New York: Oxford University.

Gard, M. (2001). Dancing around the "Problem" of Boys and Dance. Discourse: Studies in the Cultural Politics of Education, 22 (2), 213-225.

Gard, M. (2006). Men who Dance. New York: Peter Lang.

Goffman, E. (2014). Damga: Örselenmiş Kimliğin İdare Edilişi Üzerine Notlar. Ş. Geniş, L. Ünsaldı ve S. N. Ağırnaslı (Çev.). Ankara: Heretik.

Haynes, B. G. (2014). Performing Modernity in Turkey: Conflicts of Masculinity, Sexuality, and the Köçek Dancer. (Yayınlanmamış yüksek lisans tezi). The City University of New York, NY.

Heuvel, M. V. (1992). Complementary Spaces: Realism, Performance and a New Dialogics of Theatre. Theatre Journal, 44 (1), 47-58. 
Huizinga, J. (2017). Homo Ludens: Oyunun Toplumsal İşlevi Üzerine Bir Deneme. M. A. Kılıçbay (Çev.). (6. Basım). İstanbul: Ayrıntı.

Jagose, A. (2015). Queer Teori: Bir Giriş. A. Toprak (Çev.). Ankara: Notabene.

James, W. (2013). Törensel Hayvan: Yeni Bir Antropoloji Portresi. S. Çalışkan (Çev.). İstanbul: Türkiye İş Bankası Kültür Yayınları.

Johnson, C. W. (2005). 'The First Step is the Two-Step': Hegemonic Masculinity and Dancing in a Country-Western Gay Bar. International Journal of Qualitative Studies in Education, 18 (4), 445-464.

Jowitt, D. (2010). Dancing Masculinity: Defining the Male Image Onstage in Twentieth-Century America and Beyond. Southwest Review, 95 (1-2), 228-242.

Karataş, Ö. S. (2012). Osmanlı'nın Aykırı Dansçıları Tavşanlar ve Tavşanca Formu. Milli Folklor, 24: 95, 289-99.

Karayanni, S. S. (2004). Dancing Fear and Desire: Race, Sexuality, and Imperial Politics in Middle Eastern Dance. Waterloo: Wilfrid Laurier University.

Kılıç, Ç. (2009). Zenne ve Köçek. Emine Gürsoy-Naskali ve Aylin Koç (Der.), İğdiş, Sünnet, Bedene Şiddet Kitabı içinde (s. 355-365). İstanbul: Kitabevi.

Koçu, R. E. (2015). Eski İstanbul'da Meyhaneler ve Meyhane Köçekleri. (4. Basım). İstanbul: Doğan Kitap.

Mansbridge, J. (2017). The Zenne: Male Belly Dancers and Queer Modernity in Contemporary Turkey. Theatre Research International, 42 (1), 20-36.

Nuhrat, Y. (2018). Dil Antropolojisi. Ayfer Bartu Candan ve Cenk Özbay (Haz.), Kültür Denen Şey: Antropolojik Yaklaşımlar içinde (s. 256-282). İstanbul: Metis.

Nutku, Ö. (2011). Dünya Tiyatrosu Tarihi 1: Başlangıcından 19. Yüzyıla Kadar. İstanbul: Mitos-Boyut.

Oksaçan, H. E. (2015). Sultanlar Devrinde Oğlanlar. (2. Basım). İstanbul: Agora Kitaplığı.

Özkazanç, A. ve Ağtaş, Ö. (2018). Judith Butler'ın Nefret Söylemi Eleştirisi: Dildeki Performatif ve Yaralayıcı Dil. Fe Dergi: Feminist Eleştiri, 10 (1), 1-12.

Risner, D. (2009). Stigma and Perseverance in the Lives of Boys who Dance. Lewistone: Edwin Mellen. 
Rodosthenous, G. (2007). Billy Elliot the Musical: Visual Representations of Working-Class Masculinity and the All-Singing, All-Dancing Bo[d]Y. Studies in Musical Theatre, 1(3), 275292.

Salih, S. (2002). Judith Butler. London \& New York: Routledge.

Sevengil, R. A. (2014). İstanbul Nasıl Eğleniyordu? İstanbul: Alfa.

Sevengil, R. A. (2015). Türk Tiyatrosu Tarihi. İstanbul: Alfa.

Shay, A. (2006). The Male Dancer in the Middle East and Central Asia. Dance Research Journal, 38 (1-2), 137-62.

Şener, S. (1999). Cumhuriyet'in 75. Yılında Türk Tiyatrosu. İstanbul: Türkiye İş Bankası Kültür Yayınları.

Ünlü, A. (2006). Türk Tiyatrosunun Antropolojisi. Ankara: Aşina Kitaplar.

Weber, C. L. (2003). “Oi. Dancing Boy”: Masculinity, Sexuality, and Youth in Billy Elliot. Genders.

Weeks, K. (2013). Feminist Öznelerin Kuruluşu. İ. Özküralpli (Çev.). İstanbul: Otonom.

Yalur, T. (2013). Osmanlı'da Bir Cinsel Kimlik Olarak Köçek. Berfu Şeker (Haz.), Başkaldıran Bedenler: Türkiye'de Transgender, Aktivizm ve Altkültürel Pratikler içinde (s. 67-81). İstanbul: Metis. 